\title{
Sporadic flowering of Bambusa tulda in Mizoram: A preliminary report
}

\author{
David C. Vanlalfakawma ${ }^{1 *}$, F. Lalnunmawia ${ }^{2}$, Sukanta Kumar Sen ${ }^{1}$, S.K. Tripathi ${ }^{3}$ \\ ${ }^{\mathrm{I}}$ Department of Botany, Visva Bharati University, Santiniketan 731235, West Bengal, India \\ ${ }^{2}$ Department of Botany, ${ }^{3}$ Department of Forestry, Mizoram University, Tanhril 796004, India
}

\begin{abstract}
Bambusa tulda Roxb. is a semi-deciduous caespitose bamboo endemic to Indo-Burma. It is known as 'rawțhing' in Mizoram, India, and its mass gregarious flowering is called țhingtâm. 'Ṭhingtâm' has a cycle of about 45-50 years. The first țhingtâm, recorded in the region was in 1880, which was preceded by mautâm (gregarious flowering of Melocanna baccifera) in 1862; i.e., the țhingtâm phenomenon occurred 20 years after the Mautâm. The last thingtâm was recorded in 1981. However, there has been a localised thingtâm at Zawlnuam, a village at the northwestern Mizoram. The first flowering was recorded in 2015. This unusual phenomenon needs to be investigated.
\end{abstract}

Key words: Bambusa tulda; flowering; țhingtâm, Zawlnuam.
Received 30 August 2017 Accepted o7 September 2017

*For correspondence $\bowtie$ cfakawma@gmail.com
'Ṭhingtâm' is a phenomenon given to the gregarious flowering of Bambusa tulda, locally called as 'rawţhing' in Mizoram, Northeast India. As documented by numbers of native authors, the phenomenon occurs every 45-50 years. The first thingtâm, recorded in the region was in 1880 , which was preceded by mautâm (gregarious flowering of Melocanna baccifera) in 1862; i.e., the thingtâm phenomenon occurred 20 years after the Mautâm.

Bambusa tulda Roxb., a semi-deciduous caespitose bamboo, endemic to Indo-Burma is widely distributed in India, Bangladesh, Myanmar and Thailand.,2 In India it is commonly found in the northeastern states - Assam, Bihar, Meghalaya, Mizoram, Nagaland and Tripura, it is also abundantly found in West Bengal. It is a multiple used bamboo; throughout the northeast India, it is chiefly used for constructional purposes, prickles, toys, mats, food grain containers, baskets and other traditional items. ${ }^{3}$ Young shoots are consumed and shared a high market value.

Flowering of B. tulda was first documented in the years 1880-1884 and 1928-1929 in its native habitat; sporadic flowering since 1976, followed by mass flowering until 1979 were reported. ${ }^{4}$ Sporadic flowering of B. tulda in 1997 followed by gregarious flowering in 2003 was reported from Dhemaji and Lakhimpur, Assam. ${ }^{5}$ In 2003, sporadic flowering was noticed and reported from Dighra, West Bengal. ${ }^{6}$

In recent years, Mizoram, known for its rich bamboo resources has been experiencing flower- 

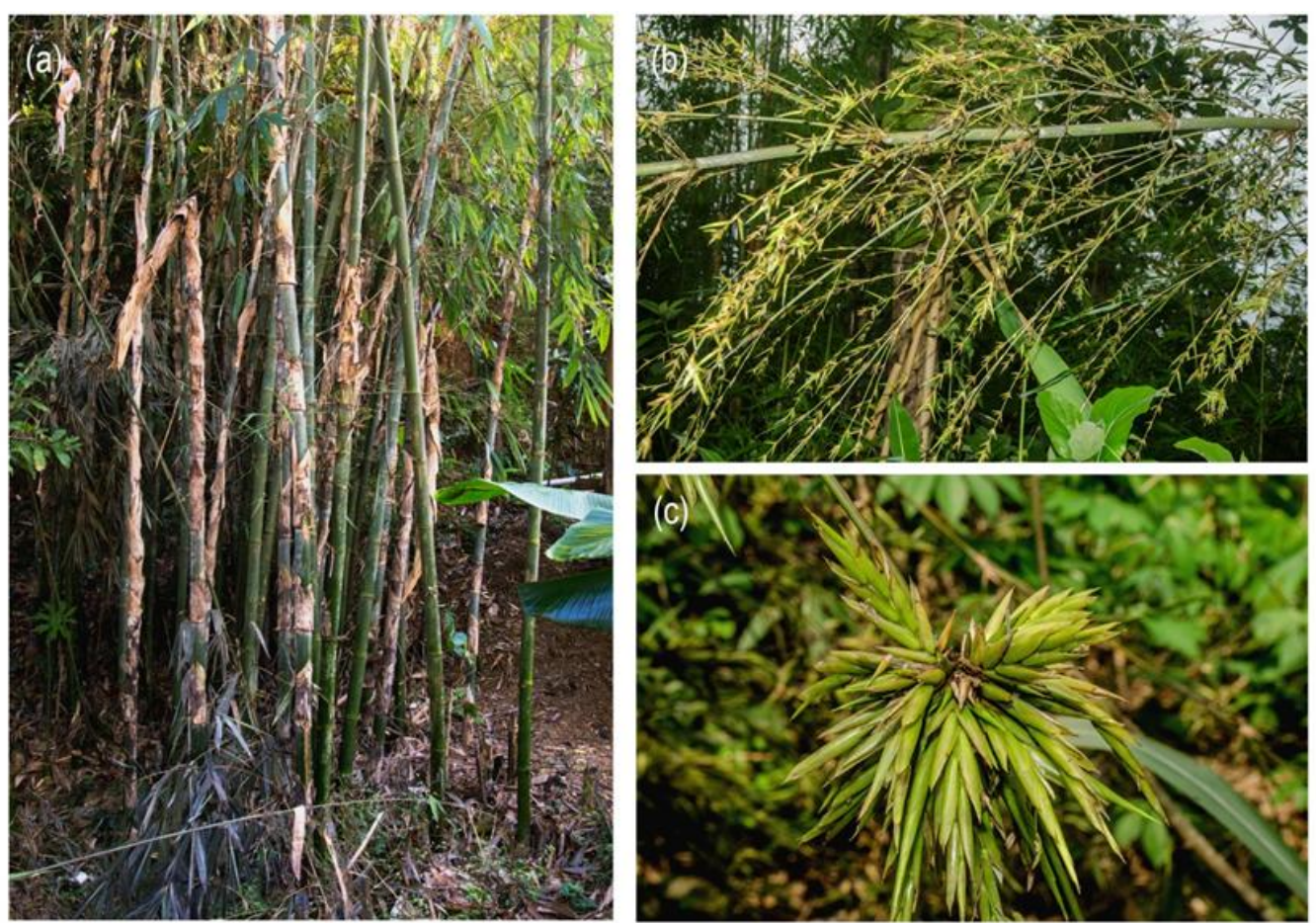

Fig. 1. Sequence of events in bamboo flowering. (a) Pre-flower clumps of $B$. tulda. (b) Culm of flowering B. tulda. (c) B. tulda flower.

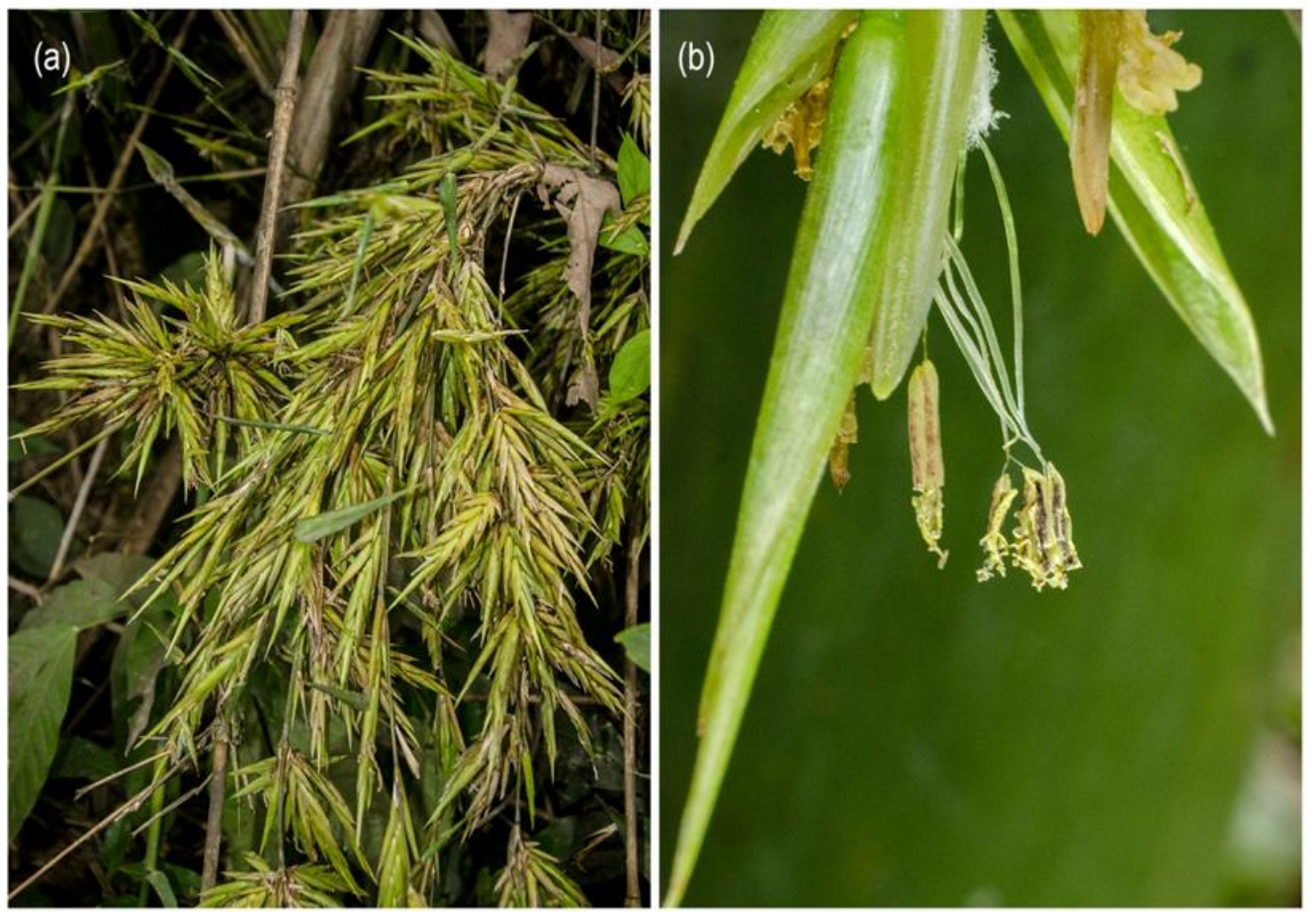

Fig. 2. (a) Inflorescence of $B$. tulda. (b) Close up of $B$. tulda flower. 
ing of bamboo (Mellocana baccifera) during 20062009 and sporadic flowering of Dendrocalamus longispathus since 2011 continuing till date? Since 1981, there has been no report or observance of flowering of B. tulda in the state. ${ }^{4}$

A survey conducted by the authors observed sporadic flowering of $B$. tulda at several locations at Zawlnuam and its surrounding villages. Zawlnuam village is located at $24^{\circ} 08^{\prime} 05.01^{\prime \prime} \mathrm{N}$ and $92^{\circ}$ $20^{\prime} 05.60^{\prime \prime} \mathrm{E}$ at an elevation of $78 \mathrm{~m} \mathrm{msl}$. Flower initiation of B. tulda was first observed in the month of February, 2015 and continued through the year (Fig. 1 \& 2). However, a recent survey indicated that the flowering is confined only to specific locations around the Zawlnuam village and no sign of flowering have been observed elsewhere, till date.

Earlier report ${ }^{4}$ suggested that the flowering cycle of the species is 48 years; the observance of sporadic flowering in an unusual timing is a matter of concern and required further study. It would also be appropriate to strengthen research to determine the impact of the postflowering die-off of the species on the associated floral and faunal diversities, including the soil micro-biota.

\section{Acknowledgement}

The authors are grateful to the Dr. Lalsangzuala Tochhawng, Medical Officer Zawlnuam PHC and Staff for first-hand information and their assistance in the field work.

\section{References}

I. Banik, R. L. (1998). Investigation on culm production and clump expansion behavior of five bamboo species of Bangladesh. Indian Forester II4 (9), 576-583.

2. Singh, P.K., Devi, S.P., Devi, K.K., Ningombam, D.S. and Athokpam, P (2010). Bambusa tulda Roxb. in Manipur state, India: Exploring the local values and commercial implications. Notulae Scientia Biologicae 2(2), 35 -40 .

3. Tewari, D. N. (1992). Monograph on Bamboo. International Book Distribution, Dehradun, India. ISBN: 8170891760, 9788170891765

4. Mohan Ram HY, Harigopal B (198I). Some observations on the flowering of bamboos in Mizoram. Current Science 5o, 708-710.

5. Sarma, H., Sarma, A.M., Sarma, A. and Borah, S. (2010). A case of gregarious flowering in bamboo, dominated lowland forest of Assam, India: phenology, regeneration, impact on rural economy, and conservation. Journal of Forestry Research 2I(4), 409-4I4.

6. Bhattacharya, S., Das, M., Bar, R. and Pal, A. (2006). Morphological and molecular characterization of Bambusa tulda with a note on flowering. Annals of Botany 98, 529-535.

7. Sharma, H.R., Yadav, S., Deka, B., Meena, R.K. and Bisht, N.S (2014). Sporadic flowering of Dendrocalamus longispathus (Kurz) Kurz in Mizoram, India. Tropical Plant Research I(I), 26-27. 